\title{
Why Judaism and Islam Prohibit Eating Pork and Consuming Blood as a Food?
}

\author{
Ilia Brondz \\ Norwegian Drug Control and Drug Discovery Institute (NDCDDI), Ski, Norway \\ Email: ilia.brondz@gmail.com
}

How to cite this paper: Brondz, I. (2018) Why Judaism and Islam Prohibit Eating Pork and Consuming Blood as a Food? Voice of the Publisher, 4, 22-31. https://doi.org/10.4236/vp.2018.42003

Received: April 19, 2018

Accepted: June 22, 2018

Published: June 25, 2018

Copyright $\odot 2018$ by author and Scientific Research Publishing Inc. This work is licensed under the Creative Commons Attribution-NonCommercial International License (CC BY-NC 4.0). http://creativecommons.org/licenses/by-nc/4.0/ (c) (i) (9) Open Access

\begin{abstract}
To date, many influential religious leaders from both Judaism and Islam have attempted to provide answers to the question of why both these religions prohibit eating pork. The most straightforward answer is that the Lord has prohibited the eating of pork and all unclean meat, including unclean fish, birds, mammals and other creatures. Followers of Judaism and Islam, respectively, must eat only kosher or halal food. Prohibitions on eating unclean food are written in the Torah and in the Koran: "He hath only forbidden you dead meat, and blood, and the flesh of swine, and that on which any other name hath been invoked besides that of Allah. For Allah is Oft-forgiving Most Merciful" (Surah the Cow 2: 173), and "He has only forbidden you dead meat, and blood, and the flesh of swine, and any (food) over which the name of other than Allah has been invoked. For Allah is Oft-Forgiving, Most Merciful" (Surah the Bee 16: 115). In principle, the laws governing kosher food in the Torah are the similar. Their traditional prohibition on eating pork and unclean food has often been used as an excuse to spark hatred of Jews and Muslims. In this paper, we attempt to study the possible sources of the prohibition to provide evidence-based answers as to why the prohibition exists, and to counter the xenophobic misrepresentations and slurs on these subjects. As it is not possible to cover all aspects of kosher and halal food in a short paper, we focus on examining the prohibition on Jews and Muslims on eating pork, human flesh and blood from all sources and, particularly, using the blood of mammals in the preparation of food.
\end{abstract}

\section{Keywords}

Islam, Judaism, Prohibition on Eating Pork, Prohibition on Consuming Blood as a Food, Domestic Pig, Sus scrofa domesticus, Kosher, Halal 
Thou shall not lie or give false testimony.

Exodus 12: 1-17 \& Deuteronomy 5: 6-21.

They invoke a curse of God if they lie (24: 7).

Hide not the testimony (2: 283).

\section{Surah the Verse.}

The Ten Commandments and their Confirmation in the Koran, as written by Dr. Shahid Athar.

\section{Introduction}

The domestic pig Sus scrofa domesticus ( $S$. s. domesticus) belongs to species: $S$. scrofa, genus: Sus is commonly called swine, hog or, simply, pig. It is the source of pork (the meat of the pig) and other products. The wild boar, wild swine or Eurasian wild pig is an ancestor of the domestic pigs in many parts of the world. Miniature pigs (also known as micro pigs, teacup pigs and other such names) are kept as pets. It is possible that pigs are the first domesticated animals. Regardless, the archaeological evidence suggested that pigs were domesticated in the Near East, possibly in the Tigris Basin in 13,000-12,700 BC [1]. In China, wild pigs were domesticated around $8,000 \mathrm{BC}$ and their importance to economic well-being in China is indicated by the fact that the same hieroglyph is used to express both house and pig.

The wild boar (see Figure 1) and all other pigs are omnivorous. They are able to consume plants and animal food, including, in the wild, carrion. The diet of both wild boars and pigs and the domesticated pig can consist of roots, tubers, bulbs, nuts, oil cakes, berries, husks, fruits, seeds, brans, green leaves, twigs, shoots, earthworms, insects, mollusks, fish, rodents, insectivores, bird eggs, birds, lizards, snakes, frogs, mushrooms, milk and all milk products, inclusive of milk powder and powder produced from water after cheese fermentation. In practice, pigs can consume all human food and drinks, but they become ill from strong alcoholic drinks. Like humans, they can be poisoned by poisonous mushrooms and plants or parts of plants, such as potatoes (Solanum tuberosum L.) if the potatoes have been given to them with skin which contains glycoalkaloid

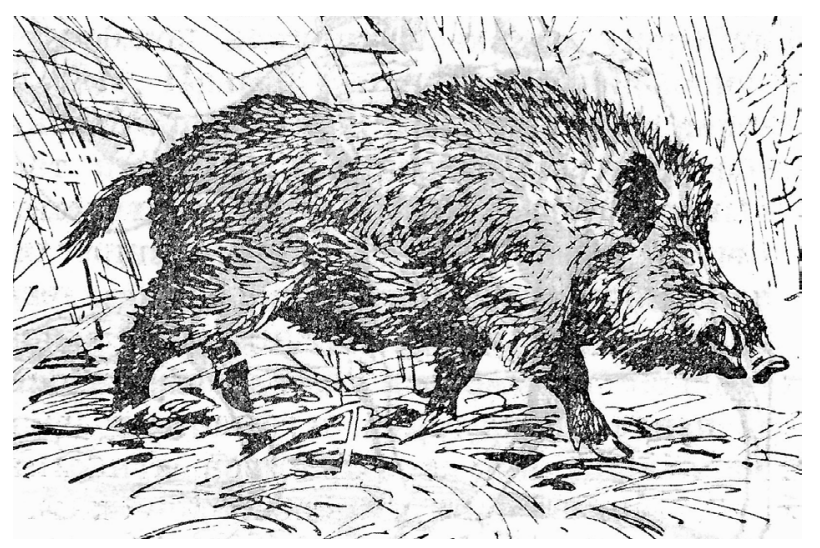

Figure 1. A wild boar. 
solanine and solasodine. Thus, they have the ability to consume a broad spectrum of vegetarian and protein-containing food.

There are well over a milliard wild and domesticated farm pigs. The production of pork is relatively cheap in comparison to the production of beef, mutton and other protein-rich foods because pigs can consume rotten products and garbage, in contrast to these other animals. Pigs can be bred for the production of pork, bacon, gammon and ham. Apart from these products, pigs are the source of intestines used for the production of natural sausages, black puddings, frankfurters and hot dogs. Pig hides, especially those from wild boars and wild pigs, are in high demand in the haberdashery and shoe industries, as well as in the furniture and cars industries. Pigs are very reproductive, with a sexual maturity age of 3 to 12 months; they have estrus every 18 to 24 days and a gestation period of only 112 to 120 days. One breed sow can farrow up to 12 piglets. Pigs are also widely used in military and clinical laboratories [2] and are possible candidates for organ donation to humans [3]. In many countries, pork is very popular, and it is a significant source of protein for the human population. Eurasian wild pig [4] or wild boar (Sus scrofa) is native to Eurasia, North Africa and the Greater Sunda Islands. Pigs have been introduced to many places where they were not previously indigenous. In some places, such as in the Pacific islands, pigs have become pests. For example, in the Galápagos archipelago, they annihilated the entire population of the Galápagos tortoise complex or Galápagos giant tortoise complex (Chelonoidis nigra). There is a growing population of wild boars, wild pigs and domesticated pigs. These become wild in Eurasia and North America because humans have reduced the numbers of their main predators, the gray wolf. In some areas of Eurasia and particularly in the Americas, they have become pests, at times coming into violent conflict with humans and pets. In addition, they are known for destroying agricultural crops, eating tree seeds and seedlings, outcompeting native species for food, damaging water quality and carrying diseases that can transmit to both domestic pigs and humans, including brucellosis, trichinosis and pseudorabies. More than 20 different parasitic worm species that are known to affect wild boars and domestic pigs can infect humans. Some dangerous invasive infections known among wild boars and domestic pigs can spread to humans include tularemia, anthrax and trichinosis (Trichinella spiralis).

\subsection{European (Celtic), Indo-European and Asia-Minor Mythology and Cultures}

Killing boar has been considered proof of a hunter's strength, courage and success from the Neolithic period, as depicted on pillars at Göbekli Tepe 12,000 years ago [5] [6] [7].

In Greek mythology, many famous heroes fought or killed wild boar; for instance, Herakles captured the Erymanthian Boar in his third labor and Theseus slew the wild sow, Phaea [8]. In addition, Greek mythology has used the wild boar to symbolize darkness, winter and death. Adonis (Greek: 'A $\delta \omega v i \varsigma$, pronun- 
ciation: [ádo:nis]) was killed by a wild boar and his death has symbolized the rotation of seasons from autumn through winter and, later, a rebirth through spring and summer. The entire mythology about Adonis has been borrowed from the Semitic mythology of the Canaanite tribes and the word Adon means

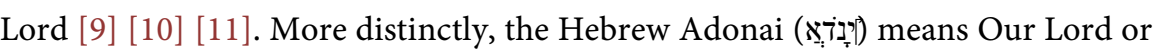
Our God, and it is used in Judaism as one of the eight names of the Lord [11]. Similarities can be observed with the death and rebirth stories of many ancient deities, including the Egyptian Osiris, the Semitic Tammuz and Baal Hadad, the Etruscan Atunis and the Phrygian Attis. Despite the variations existing in every story of death and rebirth for every deity, it appears that it was necessary to be killed and reborn to become an ancient deity. Even the story of the death and rebirth of Jesus Christ follows a similar pattern.

\subsection{Ancient Egyptian Mythology: A Story about Osiris}

Of interest to our investigation is a story regarding Osiris, the oldest son of the god Geb or, according to other sources, the son of the sun god, Ra [12]. Osiris was murdered by his brother Set, according to Plutarch, or, following Diodorus Siculus, by his evil brother Typhon, who was identical to Set. There are many variations on this particular story but, in one version, Set murdered Osiris by placing a black boar in one of Osiris's eyes. It should be mentioned that, in ancient Egyptian mythology, Osiris was a God who brought to the Egyptians the knowledge of written language, pottery, agriculture, domestication of animals and many other skills. He also persuaded the Egyptians to abolish cannibalism and to cease eating human and primate flesh. In other words, he brought civilization to the Egyptians. Osiris and the mythology about Osiris significantly predate all other mythologies about Tammuz, Baal Hadad, Atunis, Attis and Adonis and the Biblical texts.

\subsection{Cannibalism and the Eating of Human and Primate Flesh}

The fact that cannibalism was abolished in Egypt is very important, because long after Osiris persuaded the Egyptians to abolish cannibalism and to stop eating human and primate flesh, these practices persisted in many parts of the globe. Even today, cases of cannibalism are not isolated events in some regions. The habit of eating primate flesh (bushmeat) is common in Africa (among non-Muslim Negros) and, in South America, the hunting of monkey and small apes for food is common among indigenous Indians. A list of incidents of cannibalism has been presented in Wikipedia, the free encyclopedia [13]. When the English first arrived in New Zealand, and well after this time, cannibalism was known to occur among the Māori. A well-documented case of cannibalism known as the Boyd massacre occurred in 1809 [13]. Missionaries were often cannibalized, with one such incident occurring in 1901 on Goaribari Island, Papua New Guinea, when missionaries Oliver Fellows Tomkins and James Chalmers were cannibalized by the indigenous people [13]. Indeed, the most recent 
cases described in the list of incidents of cannibalism are dated September 2017 [14] [15].

The Canadian Veterinary Journal [16] describes a case of cannibalism among pigs. Farmers are well aware that cannibalism occurs among pigs, particularly adult boars that eat young piglets. In the middle ages, there were numerous descriptions of boars and pigs that killed and ate human babies. Criminal cases conducted against pigs that were involved in killing and eating humans are described in the book of Игорь Иванович Акимушкин, Свинья-самое скороспелое и “преступное" животное, Мир животных-1-е издание-М.: Молодая гвардия, 1977-1981-Т.6.-(Эврика) https://profilib.net/chtenie/158942/igor-akimushkin-mir-zhivotnykh-tom-1-lib. php.

Without doubt, this type of behavior by pigs was known in ancient Egypt. As a result of such knowledge, and because he was murdered with the assistance of a black boar, Osiris persuaded the Egyptians not to eat pork.

\subsection{The Ancient Egyptian Culture}

The walls of ancient Egyptian tombs and temples are full of pictures and frescoes that indicate the lifestyles and occupations of the ancient Egyptians. The farming of birds and animals, such as donkeys, horses and cattle, are frequently depicted. However, to the author's good knowledge, despite an extensive search, there is no evidence that pigs were farmed or hunted by the ancient Egyptians. It is well known that the death of Tutankhamun, the Egyptian pharaoh of the 18th dynasty (who ruled c. 1332-1323 BC), occurred when hunting gazelles. Another pharaoh, Menes, (according to Manetho) was killed while hunting hippos. However, there are no pictures that exist of the pharaohs or other ancient Egyptians hunting boars or pigs. Nor is there any pictorial evidence that the ancient Egyptians farmed pigs.

Many of the ancient Egyptian gods and goddesses were depicted as animals or humans with animal heads. These include Am-heh, a man with the head of a hunting dog; Anubis, a canine or a man with a canine head; Apedemak, a man with a lion head or a three-headed leonine god with four arms; Apis or Hapis, a bull; Ash, a human with the head of a lion, vulture, hawk or snake; Bast, a cat or lioness; Bennu, a bird; Hatmehit, a fish, Hededet or Hedjedjet, a man with the head of a scorpion; Heryshaf, a man with the head of a ram; Horus, a falcon and Kherty, a ram [17] [18]. However, there is no pictorial or written evidence from ancient Egypt that their gods and goddesses were ever boars or pigs or had the heads of boars or pigs. This is one more piece of evidence that pigs filled the ancient Egyptians with disgust and horror.

\subsection{Semitic Heritage}

Before the Exodus, the Semites lived in ancient Egypt for more than 400 years and they adopted many of the ancient Egyptian customs. Among these were the 
prohibition about eating unclean food and the custom of circumcision. Both customs persist among Semites (Arabs and Jews) today. Moses was a member of a pharaoh family (possibly an ancient Egyptian priest) and, in the Sinai desert, he was a founder of Judaism. The prohibition on eating unclean food was profoundly embedded in his mind. Islam was born among the Arabs, a Semitic people, in the tribe of the Hashemites, the tribe highest in the Arab hierarchy. Mohamed was one of the Hashemites. It is not clear whether the halal custom existed among the Arabs prior to Islam or whether it was introduced by Islam. Nevertheless, in the hot desert climate, the adoption of kosher and halal practices was vital for people's health and well-being. Thus, it was a wise choice of the Prophets to hear the Lord's instructions and introduce the prohibition on the eating of unclean food.

\section{Prohibition on Consuming Blood as a Food}

It should be noted that the consumption of all types of blood, even that from clean creatures, is defined as unclean and prohibited in Islam: "He hath only forbidden you dead meat, and blood, and the flesh of swine, and that on which any other name hath been invoked besides that of Allah. For Allah is Oft-forgiving Most Merciful" (Surah the Cow 2: 173). The prohibition on consuming blood is embedded in Judaism, as described in detail by the kashrut rules (https://en.wikipedia.org/wiki/Kashrut\#Permitted_and_forbidden_animals), such as the following: "When an animal is ritually slaughtered (shechted) the raw meat is traditionally cut, rinsed and salted, prior to cooking. Salting of raw meat draws out the blood that lodges on the inner surface of the meat". In the Bible, it is stated very clearly that "Only be steadfast in not eating the blood; for the blood is the life; and thou shalt not eat the life with the flesh" (Deuteronomy

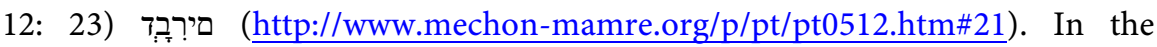

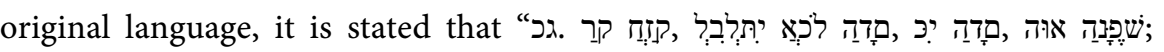

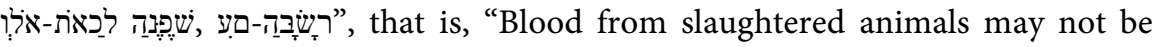
consumed, and it must be drained out of the animal and covered with earth" (Leviticus 17: 12-13). There is no doubt that, based on the Lord's words, Islam and Judaism strongly prohibit their followers consuming carrion, unclean food and blood from any sources.

\section{Blood Libel: Xenophobia, Anti-Semitism and Islamophobia}

During the dark middle ages, Christians frequently accused Jews, Muslims, heretics and members of other religions of using blood from Christian children for rituals. Later, the blood libel against Jews and Muslims was recognized by the Holy Church as an unfounded lie; indeed, such accusations had earlier been used against Christians during the time of the Roman Empire. The Papacy (the Roman Catholic Church) generally contradicted and opposed these accusations. For instance, Pope Innocent IV took action against the blood libel against Jews and Arabs in his " 5 July 1247 Mandate to the prelates of Germany and France to annul all measures adopted against the Jews on account of the ritual murder li- 
bel, and to prevent accusation of Arabs on similar charges"

http://www.newadvent.org/cathen/08017a.htm. Pope Gregory X (1271-1276) wrote on the same topic, in his "Letter on Jews (1271-76) -Against the Blood Libel" https://sourcebooks.fordham.edu/halsall/source/g10-jews.asp. Later, Pope Paul III, in a bull dated 12 May 1540, made clear his displeasure with the Hungarian, Bohemian and Polish enemies of the Jews, who had spread false accusations of Jews killing children and drinking their blood as a pretext to seize Jewish property.

Interestingly, the Muslim Sultan of the Ottoman Empire, Suleiman the Magnificent, also denounced the blood libel against the Jews in a royal decree dated 1553-1554 [19]. Other state leaders took similar actions, including Frederick II, the Holy Roman Emperor (1194-1250), Přemysl Ottokar II, the King of Chechia (1233-1278), Rudolf von Habsburg, known as Rudolf I, the King of Germany (1218-1291), Albrecht I von Habsburg, the King of Germany (1255-1308), Václav II, the King of Chechia (1271-1305) and Alexander I, the Emperor of Russia (1777-1825).

\section{Blood libel: The Russian Empire and the Black Squadrons (Чёрная сотня)}

In the Russian Empire, the blood libel accusations against the Jews were spread by the members of the Black Squadrons, also known as the Black Hundred/s (in Russian: Чёрная сотня, Chornaya sotnya), an ultranationalist movement that staunchly supported the Royal House of Romanov. The Black Hundreds were known for their extremism and incitement of pogroms and their various xenophobic beliefs, including Ukrainophobia, anti-Semitism and Islamophobia [20] [21] [22]. In cooperation with the secret police, the Black Hundreds fabricated to falsify proofs against the Russian Jew, Menahem Mendel Beilis (1874-1934), accusing him of ritual murder on March 12, 1911

https://en.wikipedia.org/wiki/Menahem_Mendel_Beilis. A report was submitted to the Emperor of the Russian Empire, Nicolai II, who was himself a staunch supporter and, indeed, a member of the Black Hundreds. Tsar Nicolai II gave his approval to start the trial against Beilis. A student, Vladimir Golubev, who was the leader of the Two-Headed Eagle, the offspring organization from Black Hundreds, fabricated the false proof against Beilis. None of the Russian Orthodox Christian priests were willing to act in the trial as religious experts on Judaic rituals, to support the accusations. However, a Lithuanian Catholic priest, Justinas Bonaventura Pranaitis (1861-1917), was willing to act as an expert to support the accusations https://en.wikipedia.org/wiki/Justinas_Pranaitis. A Russian Orthodox priest, Aleksandr Glagolev (1872-1937), also a Professor of the Kiev Theological Seminary of the Orthodox Christian, was the defense expert. He presented the Laws of Moses as evidence, which forbid using any blood in food (Deuteronomy Chapter 12 and Leviticus 17: 12-13). Several prominent experts also participated in the defense, including Professor Vladimir M. Bekhterev, 
Professor Ivan G. Troitsky and Rabbi Yakov Mazeh. The defense demonstrated that Pranaitis, the Lithuanian Catholic priest, lacked credibility in his knowledge of Talmudic concepts and definitions. Ultimately, despite the fact that seven of the 12 Christian jurors were members of the Union of the Russian People (one of the offspring organizations of the Black Hundreds), after deliberating for several hours, the jury acquitted Beilis. Up to this point, the trial lasted more than two years. Significant evidence in defense of Beilis was provided by a Russian detective Nikolai Krasovsky, who determined that the true murderers were connected to the Black Hundreds and the secret police.

\section{Conclusions}

In this paper, we have discussed two opposing religious ideological concepts, on which two cultural civilizations are based. One culture is relaxed about the consumption of pork and blood as a food (and its members consume food such as black puddings, frankfurters and hot dogs). The other cultures are based on a religious ideology that strongly prohibits the consumption of pork and of blood as a food: "He hath only forbidden you dead meat, and blood, and the flesh of swine, and that on which any other name hath been invoked besides that of Allah. For Allah is Oft-forgiving Most Merciful" (Surah the Cow 2: 173) and "Only be steadfast in not eating the blood; for the blood is the life; and thou shalt not eat the life with the flesh" (The Bible, Deuteronomy Chapter 12: 23 סירְְ?

Today, racism, xenophobia, anti-Semitism, Islamophobia and Ukrainophobia have influenced millions of people in all parts of the world. Racism, xenophobia and Islamophobia prevail generally. However, it should be noted that, historically, in the same countries these have been deep-rooted in anti-Semitism where Islamophobia also has been and is widespread. In Poland and the former Baltic Republics of the Soviet Union, deep-rooted anti-Semitism and Islamophobia have existed historically and continue to do so. For instance, Poland and the Baltic Republics have actively prevented Turkey joining the Europe Union because of its predominantly Muslim population and, during the 2016-2017 refugee crisis. They did not permit the entry of a single refugee from Syria, Iraq, Afghanistan or Africa because the refugees were Muslims.

The Russian Federation has adopted the traditions of the Russian Empire and the Soviet Union. Russian politician and right-wing extremist Vladimir Mitrofanovich Purishkevich (1870-1920) was one of the founders of the Union of the Russian People (a branch of the Black Squadrons). He was the deputy to the Russian state Dumas (parliaments) (1906-1917) and a very active xenophobe, Ukrainophobe, anti-Semite and Islamophobe. He was a leader of one faction in the Duma (in reality, he represented the thoughts of Tsar Nicolai II, who was also a staunch anti-Semite and Islamophobe). In 1990th, during the first and second Chechnya war, the most active xenophobe and Islamophobe was the leader of the Liberal Democratic Party of Russia, Vladimir Vulvovich Zhirinovsky (Эйдельште́йн) [23] 
https://en.wikipedia.org/wiki/Vladimir_Zhirinovsky. He is a converted Jew, a staunch anti-Semite and a racist [24] [25]. In recent years, he has actively presented strong anti-Ukraine sentiments [26] [27], which represented the official state position of the Kremlin. Following Vladimir Vulvovich, the Ukraine does not have its own territories [27], as these belong to Poland, Hungary, Romania and Russia [27].

\section{References}

[1] Nelson, S.M. (1998) Ancestors for the Pigs, Pigs in Prehistory. University of Pennsylvania. http://www.upenn.edu/pennpress/book/13685.html

[2] Brondz, I. (2016) Super Antibiotics, Part II. Hyperforin, Mass Spectroscopy (MS) and Gas Chromatography-Mass Spectrometry (GC-MS), Evidence of Permeability of the Blood-Testis Barrier (BTB) and the Blood-Brain Barrier (BBB) to Hyperforin. International Journal of Analytical Mass Spectrometry and Chromatography, 4, 66-73. https://doi.org/10.4236/ijamsc.2016.44007

[3] Dooldeniya, M.D. and Warrens, A.N. (2003) Xenotransplantation: Where Are We Today? JRSM, 96, 111-117. https://doi.org/10.1258/jrsm.96.3.111

[4] Oliver, W.L.R. Brisbin Jr., I.L. and Takahashi, S. (1993) The Eurasian Wild Pig (Sus scrofa). In: Oliver, W.L.R., Ed., Pigs, Peccaries, and Hippo: Status Survey and Conservation Action Plan, 112-121.https://portals.iucn.org/library/node/6805

[5] Mann, C.C. (2011) Göbekli Tepe: The Birth of Religion, National Geographic. http://solutions.cengage.com/uploadedFiles/solutionscengagecom/Marketing-Micro sites/NGL/design-gallery/Religion.pdf

[6] Scham, S. (2008) The World's First Temple. Archaeology, 61. https://archive.archaeology.org/0811/abstracts/turkey.html

[7] Mann, C.C. (2011) The Birth of Religion-National Geographic Magazine-NGM.com. http://ngm.nationalgeographic.com/print/2011/06/gobekli-tepe/mann-text

[8] Mallory, J.P. and Adams, D.Q. (1997), Encyclopedia of Indo-European Culture. Taylor \& Francis, 426-428.

https://www.amazon.com/Encyclopedia-Indo-European-Culture-James-Mallory/dp 11884964982

[9] Burkert, W. (1985) Greek Religion. Harvard University Press, Cambridge. http://www.hup.harvard.edu/catalog.php?isbn=9780674362819

[10] Burkert, W. (1987) Greek Religion: Archaic and Classical. https://www.amazon.co.uk/Greek-Religion-Archaic-Classical-Ancient/dp/06311562 $\underline{40}$

[11] Botterweck, G.J. and Ringgren, H. (1974) Theological Dictionary of the Old Testament. Eerdmans Publishing, Vol. 1, 59-74.

https://www.amazon.com/Theological-Dictionary-Old-Testament-Set/dp/08028233 $\underline{86}$

[12] Wilkinson, R.H. (2003) The Complete Gods and Goddesses of Ancient Egypt. Thames \& Hudson, London, 105.

[13] https://en.wikipedia.org/wiki/List_of_incidents_of_cannibalism

[14] Stewart, W. (2017) Final Victim of Russia's "Cannibal Couple Who Butchered 30 People to Make Meat PIES" Was Murdered in Their "Killing Crypt" in a Row over an Affair. Daily Mail.

http://www.dailymail.co.uk/home/search.html?s=\&authornamef=Will+Stewart+for 
+MailOnline

[15] Hjelmgaard, K. (2017) Russian "Cannibal Couple” Confess to Eating 30 People, Sold "Meat Pieces" at Army Base, Police Say. USA Today. https://www.usatoday.com/story/news/world/2017/09/27/russian-cannibal-couple-c onfess-eating-30-people-sold-meat-pieces-army-base-police-say/707255001/

[16] Jericho, K.W. and Church, T.L. (1972) Cannibalism in Pigs. Canadian Veterinary Journal, 13, 156-159. https://www.ncbi.nlm.nih.gov/pmc/articles/PMC1695826/?page=1

[17] Hart, G. (2005) The Routledge Dictionary of Egyptian Gods and Goddesses. 2nd Edition, Routledge, Taylor \& Francis E-Library. http://shenjiva.com/HartGeorge_egyptgods2005.pdf

[18] Wilkinson, R.H. (2003) The Complete Gods and Goddesses of Ancient Egypt. Thames \& Hudson Ltd, London. http://emp.byui.edu/SatterfieldB/Rel390R/Fur\%20Further\%20Study/Divine\%20Cou ncil/Groups\%20of\%20Dieties\%20Egypt.pdf

[19] Mansel, P. (1998) Constantinople: City of the World's Desire, 1453-1924. St. Martin's Griffin, New York, 124.

[20] Potichnyj, P.J., Raeff, M., Pelenski, J. and Zekulin, G.N. (1992) Ukraine and Russia in Their Historical Encounter. University of Alberta, Edmonton, Canadian Institute of Ukrainian Studies Press. https://archive.org/stream/ukrainerussiaint00pele/ukrainerussiaint00pele_djvu.txt

[21] Internet Encyclopedia of Ukraine. Black Hundreds University of Toronto, Canadian Institute of Ukrainian Studies.

http://www.encyclopediaofukraine.com/display.asp?linkpath=pages $\% 5$ CB $\% 5$ CL $\% 5$ CBlackHundreds.htm

[22] Fernando Bravo López, F.B. (2009) Tesis Doctoral, Islamofobia y Antisemitismo: La Construcción Discursiva de las Amenzas Islámic y Judía. Universidad Autónoma de Madrid, Facultad de Filosofía y Letras, Departamento de Estudios Árabes e Islámicos y Estudios Orientales, Directores: Dr. Bernabé López García, Dra. Ana I. Planet Contreras, Dra. Christiane Stallaert, Madrid.

https://repositorio.uam.es/bitstream/handle/10486/4331/29263_bravo_lopez_fernan do.pdf?sequence $=1$

[23] https://en.wikipedia.org/wiki/Vladimir_Zhirinovsky

[24] Specter, M. (1994) The World: Here Comes the Clown. No Joke. The New York Times, 6 November 1994.

https://www.nytimes.com/1994/11/06/weekinreview/the-world-here-comes-the-clo wn-no-joke.html

[25] http://www.pravdareport.com/russia/politics/11-01-2006/9488-condoleezza-0/

[26] http://www.bbc.com/news/world-middle-east-26248275

[27] https://www.youtube.com/watch?v=vQpqSFTPTGU 